

\section{Physicochemical Properties}

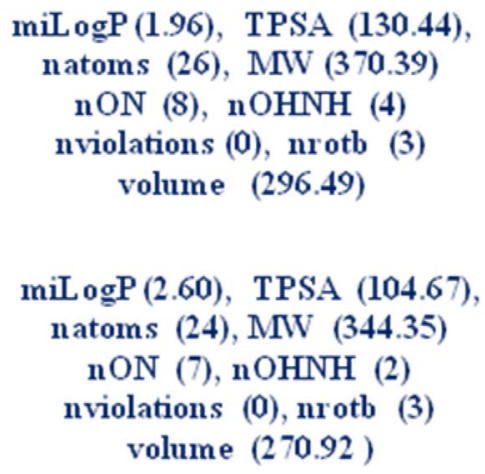

miL ogP (2.06), TPSA (103.36), natoms (24), MW (343.36), nON (7), $\mathrm{nOHNH}(2)$, nviolations (0), nrotb (3), volume (274.58)

\section{Bioactivity score}

\begin{tabular}{lr} 
GPCR ligand & 0.02 \\
\hline Ion channel modulator & -0.21 \\
\hline Kinase Inhibitor & 0.26 \\
\hline Nuclear receptor ligand & -0.29 \\
\hline Protease inhibitor & -0.04 \\
\hline Enzyme Inhibitor & 0.24 \\
\hline GPCR ligand & -0.09 \\
\hline Ion channel modulator & -0.06 \\
\hline Kinase Inhibitor & -0.09 \\
\hline Nuclear receptor ligand & -0.19 \\
\hline Protease inhibitor & -0.01 \\
\hline Enzvme Inhibitor & -0.05 \\
\hline
\end{tabular}

\begin{tabular}{lc} 
GPCR ligand & -0.33 \\
\hline Ion channel modulator & -0.47 \\
\hline Kinase Inhibitor & -0.40 \\
\hline Nuclear receptor ligand & -0.52 \\
\hline Protease inhibitor & -0.14 \\
\hline Enzyne Inhibitor & -0.14 \\
\hline
\end{tabular}

Fig. 1 Representing the drug likeness properties (physicochemical and bioactivity score) for the compounds (1-3)

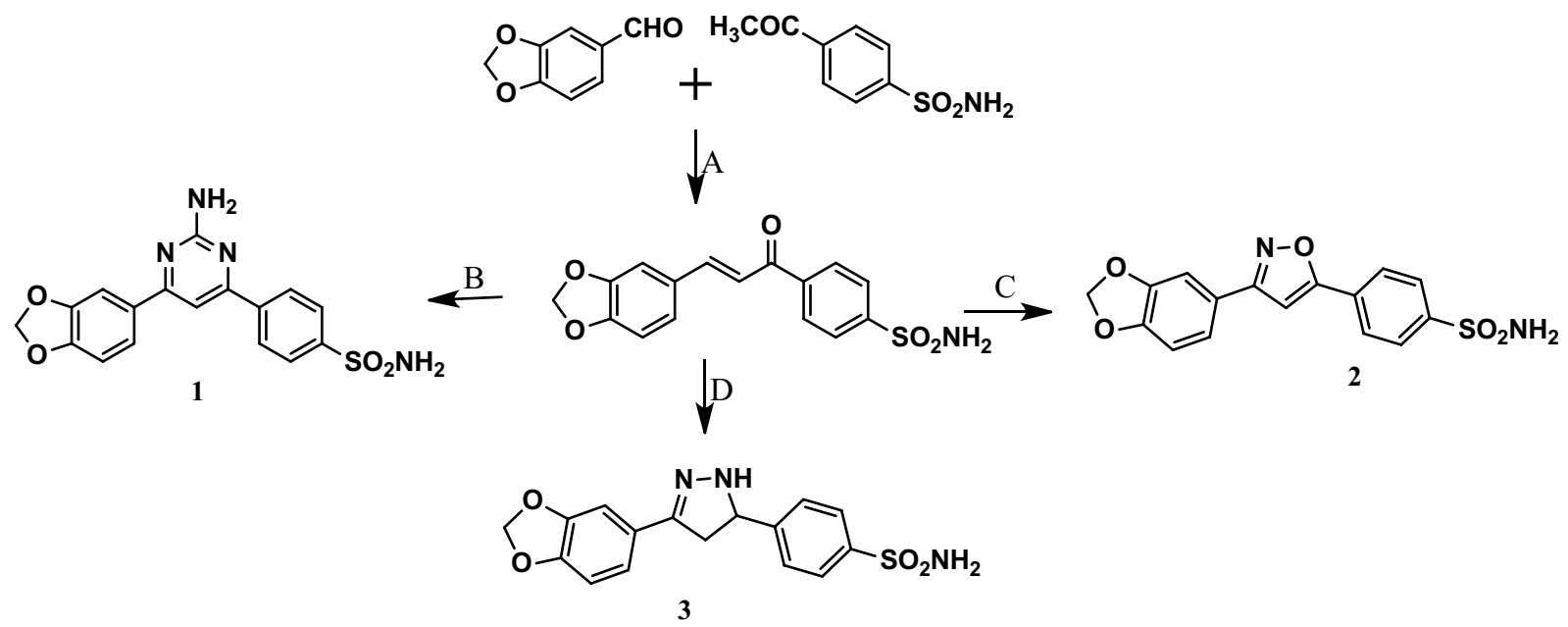

$\mathrm{A}=\mathrm{NaOH}$, Ethanol, reflux, $\mathrm{B}=$ Guanidine hydrochloric acid, isopropyl alcohol, reflux $\mathrm{C}=\mathrm{NH}_{2} \mathrm{OH} \cdot \mathrm{HCl}$, Ethanol, reflux $\mathrm{D}=\mathrm{NH}_{2} \mathrm{NH}_{2} \cdot \mathrm{H}_{2} \mathrm{O}$, Conc. $\mathrm{H}_{2} \mathrm{SO}_{4}$, Ethanol, reflux

Fig. 2 Representing the schematic diagram for the synthesis of compounds (1-3)

and 4-acetylbenzenesulfonamide to yield of 4-[(2E)3-(1,3-benzodioxol-5-yl)prop-2-enoyl]benzenesulfonamide (A). The step- 2 is different for the synthesis of compounds 4-[2-amino-6-(1,3-benzodioxol-5-yl) pyrimidin-4-yl]benzenesulfonamide [1], 4-[3-(1,3-benzodioxol-5-yl)-1,2-oxazol-5-yl]benzenesulfonamide [2] and
-[5-(1,3-benzodioxol-5-yl)-4H-pyrazol-3-yl]benzenesulfonamide [3]. The compounds- 1 undergoes the reaction (A) and guanidine hydrochloride in isopropanol under reflux condition. Compound-A reacted with hydroxylamine hydrochloride in ethanol under reflux, to yield compound-2. The compound-3 is synthesized through 
the reaction between hydrazine hydrate and compound$A$, in ethanol under reflux condition. The compounds (1-3), were then characterized for the structural confirmation by many spectroscopic methods (FT-IR, ${ }^{1} \mathrm{H}-\mathrm{NMR}$, Mass spectroscopy) and elemental analysis. The FTIR spectra for compound- 1 exhibited the signal at 1063, 1617, 3335, $3354 \mathrm{~cm}^{-1}$ due to the presence of $\mathrm{C}-\mathrm{N}, \mathrm{C}=\mathrm{N}, \mathrm{NH}_{2}, \mathrm{SO}_{2}-\mathrm{NH}_{2}$ functional groups and the absence of signal around $1700 \mathrm{~cm}^{-1}$ due to $C=0$ functional group confirmed the structure of the compound- 1 . The disappearance of the signal around $1700 \mathrm{~cm}^{-1}$ due to the $\mathrm{C}=\mathrm{O}$ functional group and the appearance of signals in the range 1619-1621, 2971-2977 and $3347-3358 \mathrm{~cm}^{-1}$ due to the presence of $\mathrm{C}=\mathrm{N}, \mathrm{CH}-\mathrm{Ar}, \mathrm{SO}_{2}-\mathrm{NH}_{2}$ functional groups confirmed the formation of compound-2 and compound-3. Further structural confirmation was carried out by the ${ }^{1} \mathrm{H}-\mathrm{NMR}$ spectra for compounds (1), the characteristic singlet at $5.971 \mathrm{ppm}$ due to $\mathrm{O}-\mathrm{CH}_{2}-\mathrm{O}$ protons, $8.114 \mathrm{ppm}$ due to $\mathrm{NH}_{2}$ protons and $8.393 \mathrm{ppm}$ due to $\mathrm{SO}_{2}-\mathrm{NH}_{2}$ protons. The H-NMR spectra of the compounds $2-3$ exhibited the singlet around 5.908-8.310 ppm and 8.310-8.408 due to the $\mathrm{O}-\mathrm{CH}_{2}-\mathrm{O}$ and $\mathrm{SO}_{2}-\mathrm{NH}_{2}$ protons respectively. The spectra of compound-3 also exhibited the double doublets around 3.19-3.26, 4.07-4.15 and 6.10-6.17 ppm due to the presence of $\mathrm{H}_{A}, \mathrm{H}_{B}, \mathrm{H}_{X}$ protons of the pyrazoline nucleus. The experimental section possessed the detailed spectroscopic data of the compounds (1-3). The screening of compounds as antimicrobial agents) was assessed by the method of disc diffusion, using the gram-positive and negative pathogens in as per the formation of inhibition zone and minimum inhibitory concentration (MIC). The respective zone of inhibition and MIC of the compounds (1-3) and reference drug Ciprofloxacin is represented in the Table 1 and the \%Area of inhibition/ $\mu \mathrm{g}$ is reported in Fig. 3. The results for antimicrobial screening portrayed that compound-1 possessed very strong similarity with the reference the drug, Compound-2 exhibited very significant antimicrobial effect against all microorganisms, while the compound- 3 was found to possess better the antimicrobial effect in comparison to the reference drug.
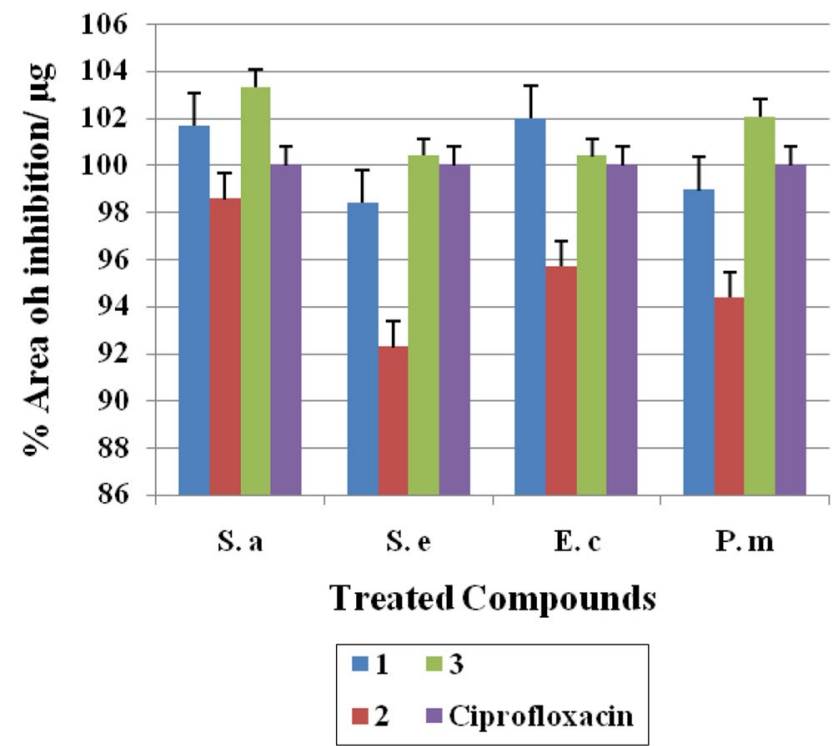

Fig. 3 Representing the percent area of inhibition per microgram of the treated compounds (1-3) and standard drug ciprofloxacin

To understand the cyto-toxicity status of the synthesized compounds the MTT assay was performed against HepG2 cells. The synthesized compounds were treated HepG2 cells with the different concentrations $(3.125,6.25 .12 .5,25$, 50 and $100 \mu \mathrm{M})$ and observed that the viability of the cells were inversely proportional to the concentration (Fig. 4). According to the protocol only the viable cells will be able to produce the formazan crystal due to the presence of mitochondrial enzymes so the formation of the colored complex will be equal to the number of viable cells. To support the experimental results and for better understanding of the antimicrobial potential molecular docking assessment was performed for all the synthesized compounds $(1-3)$ and the Ciprofloxacin. The results exhibited that a variety of the residues of GlcN-6-P-synthase were observed of forming the Hydrogen bond with the Compound-1 (SER 316, TYR 576, ASP 548), Compound-2 (LYS 487 and LEU 480), Compound-3 (CYS 300, SER 347, SER 401 VAL399, ILE

Table 1 Representing the zone of inhibition and the minimum inhibitory concentrations of the compounds (1-3) and ciprofloxacin

\begin{tabular}{|c|c|c|c|c|c|c|c|c|}
\hline \multirow[t]{4}{*}{ S. no. } & \multicolumn{8}{|c|}{ Diameter of the halo zone, $\mathrm{mm}$ and minimum inhibitory concentration (MIC) } \\
\hline & \multicolumn{4}{|l|}{ Gram-positive } & \multicolumn{4}{|l|}{ Gram-negative } \\
\hline & \multicolumn{2}{|l|}{ S. aureus } & \multicolumn{2}{|l|}{ S. epidermidis } & \multicolumn{2}{|l|}{ E. coli } & \multicolumn{2}{|l|}{ P. mirabilis } \\
\hline & Zone of inhibition & MIC & Zone of inhibition & MIC & Zone of inhibition & MIC & Zone of inhibition & MIC \\
\hline 1 & $21.75 \pm 0.18$ & 6.25 & $22.50 \pm 0.20$ & 3.125 & $24.16 \pm 0.36$ & 6.25 & $22.10 \pm 0.32$ & 12.5 \\
\hline 2 & $21.08 \pm 0.25$ & 6.25 & $21.10 \pm 0.36$ & 3.125 & $22.67 \pm 0.22$ & 6.25 & $21.08 \pm 0.25$ & 12.5 \\
\hline 3 & $22.10 \pm 0.14$ & 6.25 & $22.96 \pm 0.26$ & 3.125 & $23.78 \pm 0.20$ & 6.25 & $22.80 \pm 0.23$ & 12.5 \\
\hline Cipro & $21.39 \pm 0.21$ & 6.25 & $22.87 \pm 0.37$ & 3.125 & $23.69 \pm 0.81$ & 6.25 & $22.34 \pm 0.21$ & 12.5 \\
\hline
\end{tabular}



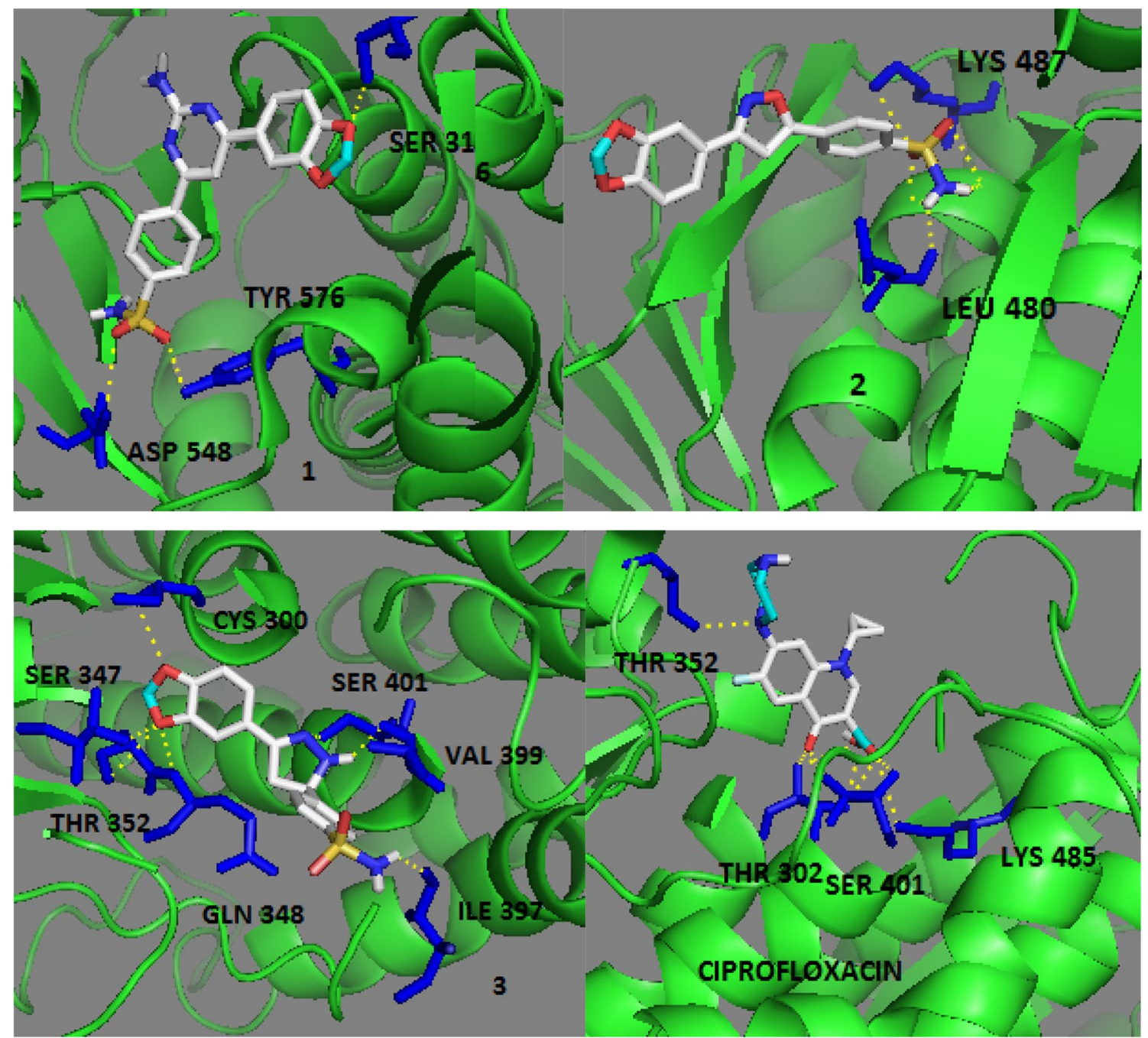

Fig. 4 Molecular docking images for the compounds (1-3) and ciprofloxacin

397, GLN 348 and THR 352) and Ciprofloxacin (THR 352, THR 302, SER 401 and LYS 485). Overall the docking assessment strongly recommended the experimental results and revealed that compound-3 represented too much better $\mathrm{H}$-bonding than the Ciprofloxacin and the similar $\mathrm{H}$-bonding is observed with only SER residues (Compound-1, 3 \& Ciprofloxacin) and SER \& THR residues (Compound-3 \& Ciprofloxacin), Fig. 5. The binding affinity of the compound-1, 2,3 and the ciprofloxacin was observed respectively in the range -7.5 to $-7.0 \mathrm{kcal} / \mathrm{mol},(-7.0$ to $-6.5 \mathrm{kcal} / \mathrm{mol}),(-7.6$ to $-6.6 \mathrm{kcal} / \mathrm{mol})$ and $(-7.1$ to $6.2 \mathrm{kcal} / \mathrm{mol})$ Table 2 .

\section{Experimental}

The schematic diagram and the structures of the compounds were drawn by ChemDraw Ultra 8.0 ChemSketch, and the computational study was performed on the Molinspiration. The required chemicals and reagents Piperonal, 4-acetylbenzenesulfonamide, $\mathrm{NaOH}$, Ethanol, Guanidine hydrochloric acid, isopropyl alcohol, $\mathrm{NH}_{2} \mathrm{OH}$. $\mathrm{HCl}$, reflux, $\mathrm{NH}_{2} \mathrm{NH}_{2} \cdot \mathrm{H} 2 \mathrm{O}$, Conc. $\mathrm{H}_{2} \mathrm{SO}_{4}$, agar, ciprofloxacin, dimethylsulfoxide, MTT, DMEM, FBS) were purchased from Sigma-Aldrich, Merck, Germany, HIMEDIA and HyClone Laboratories, Logan, UT, USA. Estimation of the progress of the reaction was performed by the thin layer chromatographic plates. Analytical techniques to confirm the structure were performed by Heraeus Vario EL III analyzer for elemental analysis, Perkin-Elmer model 1600 FT-IR RX1 instrument for FTIR spectra, Spectra Bruker Avance $300 \mathrm{MHz}$ spectrometer for NMR ( ${ }^{1} \mathrm{H}$ or ${ }^{13} \mathrm{C}$ ) spectra and Micromass Quattro II triple quadrupole mass spectrometer for mass spectra.

\section{SN Applied Sciences}




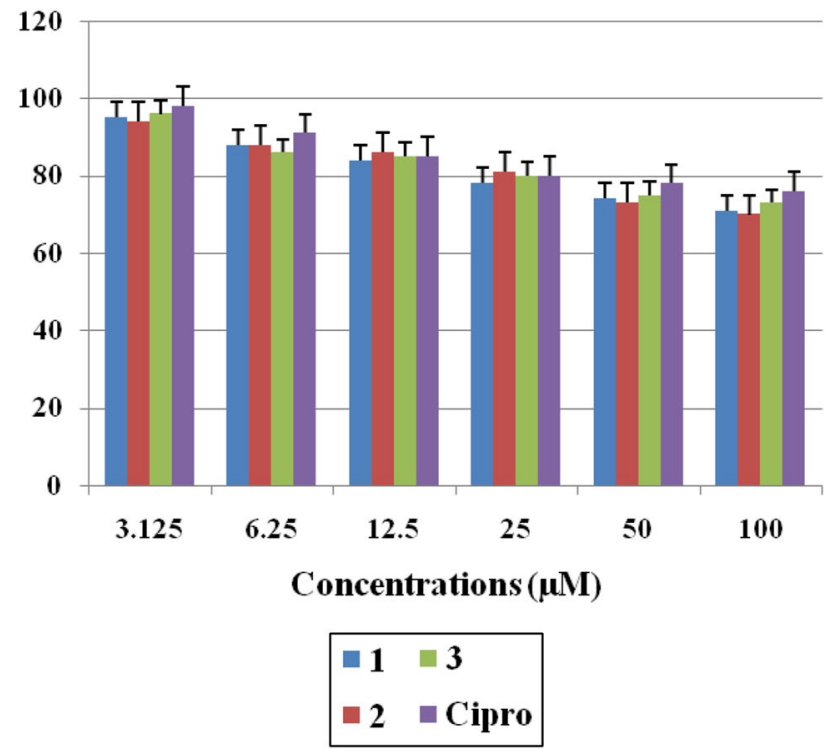

Fig. 5 Representing the percent viability of HepG2 cells on treatment of compounds (1-3) and standard drug ciprofloxacin

\subsection{Computational assessment}

Chem Draw ultra 8.0 was used to design the structures of the compounds (1-3), standard and applied for the calculation of physicochemical properties and bioactivity score by the online available software (Molinspiration), the detailed procedure is reported in [36-42].

\subsection{Synthesis and characterization}

\subsubsection{General procedure for the synthesis of 4-[(2E)-3-(1,3-benzodioxol-5-yl)prop-2-enoyl] benzenesulfonamide}

The synthesis of 4-[(2E)-3-(1,3-benzodioxol-5-yl)prop-2enoyl]benzenesulfonamide was performed by the procedure reported in [17].

\subsubsection{Procedure for the synthesis of 4-[2-amino-6-(1,3-benzodioxol-5-yl)pyrimidin-4-yl] benzenesulfonamide [1]}

4-[(2E)-3-(1,3-benzodioxol-5-yl)prop-2-enoyl]benzenesulfonamide and guanidine hydrochloride was taken in the round bottom flask, mixed with $50 \mathrm{~mL}$ of isopropyl alcohol and refluxed for $24 \mathrm{~h}$ to yield the desired compound [1].

\subsubsection{4-[2-amino-6-(1,3-benzodioxol-5-yl)pyrimidin-4-yl] benzenesulfonamide}

Yield: $85 \%$; m. p. $115-117^{\circ} \mathrm{C}$ : Light Yellow crystals; Anal. calc. for $\mathrm{C}_{17} \mathrm{H}_{14} \mathrm{~N}_{4} \mathrm{O}_{4} \mathrm{~S}$ : C 55.13, H 3.81, N 15.13; Found: $\mathrm{C}$ 55.09, H 3.84, N 15.17; FT-IR $\left(\mathrm{cm}^{-1}\right)$ : $1063(\mathrm{C}-\mathrm{N}), 1617(\mathrm{C}=\mathrm{N})$, 2995 (CH-Ar), $3335\left(\mathrm{NH}_{2}\right), 3354\left(\mathrm{SO}_{2}-\mathrm{NH}_{2}\right){ }^{1}{ }^{1} \mathrm{H}$ NMR (DMSOd6) (ppm): 5.971 (s, 2H, O-CH $-\mathrm{O}), 6.858(\mathrm{~s}, 1 \mathrm{H}, \mathrm{CH}-\mathrm{Ar})$, 7.039-7.121 (d, 1H, CH-Ar), 7.198-7.231 (d, 1H, CH-Ar), 7.337-7.502 (m, 4H, CH-Ar), $8.114\left(\mathrm{~s}, 2 \mathrm{H}, \mathrm{NH}_{2}\right), 8.393(\mathrm{~s}, 2 \mathrm{H}$, $\mathrm{SO}_{2} \mathrm{NH}_{2}$ ); $\mathrm{ESI}-\mathrm{MS}$ (m/z): [M+ +1 ]: 371.08 (Mass: 370.39 ).

Table 2 Representing the binding affinities of all the nine modes of binding with the residues of receptor (GlcN-6-P-synthase), and the distance from the best mode (upper bound or lower bound)

\begin{tabular}{|c|c|c|c|c|c|c|c|c|c|}
\hline \multirow[t]{3}{*}{ Modes } & \multicolumn{3}{|l|}{ Compound-1 } & \multicolumn{3}{|l|}{ Compound-2 } & \multicolumn{3}{|l|}{ Compound-3 } \\
\hline & \multirow[t]{2}{*}{$\begin{array}{l}\text { Binding affinity } \\
\text { (Kcal/mol) }\end{array}$} & \multicolumn{2}{|c|}{$\begin{array}{l}\text { Distance from best } \\
\text { mode }\end{array}$} & \multirow[t]{2}{*}{$\begin{array}{l}\text { Binding affinity } \\
\text { (Kcal/mol) }\end{array}$} & \multicolumn{2}{|c|}{$\begin{array}{l}\text { Distance from best } \\
\text { mode }\end{array}$} & \multirow[t]{2}{*}{$\begin{array}{l}\text { Binding affinity } \\
\text { (Kcal/mol) }\end{array}$} & \multicolumn{2}{|c|}{$\begin{array}{l}\text { Distance from best } \\
\text { mode }\end{array}$} \\
\hline & & rmsd l.b & rmsd u.b & & rmsd I.b & rmsd u.b & & rmsd I.b & rmsd u.b \\
\hline 1 & -7.5 & 0.000 & 0.000 & -7.0 & 0.000 & 0.000 & -7.6 & 0.000 & 0.000 \\
\hline 2 & -7.3 & 28.732 & 30.334 & -7.0 & 19.292 & 25.433 & -7.4 & 12.245 & 14.816 \\
\hline 3 & -7.2 & 25.757 & 27.707 & -6.7 & 9.359 & 13.519 & -7.4 & 27.567 & 28.495 \\
\hline 4 & -7.1 & 4.144 & 5.934 & -6.7 & 19.442 & 24.303 & -7.4 & 22.066 & 23.674 \\
\hline 5 & -7.1 & 25.344 & 26.747 & -6.7 & 31.710 & 33.237 & -7.1 & 12.792 & 15.899 \\
\hline 6 & -7.1 & 26.760 & 28.847 & -6.7 & 15.761 & 20.197 & -7.1 & 2.218 & 2.490 \\
\hline 7 & -7.1 & 25.833 & 26.960 & -6.6 & 17.402 & 18.548 & -7.0 & 27.671 & 29.141 \\
\hline 8 & -7.0 & 19.117 & 20.386 & -6.6 & 17.092 & 18.429 & -6.6 & 22.633 & 24.277 \\
\hline 9 & -7.0 & 27.047 & 28.012 & -6.5 & 8.792 & 11.936 & -6.6 & 28.546 & 29.466 \\
\hline
\end{tabular}


3.2.4 Procedure for the synthesis of 4-[3-(1,3-benzodioxol-5-yl)-1,2-oxazol-5-yl] benzenesulfonamide [2]

An equimolar amount of 4-[(2E)-3-(1,3-benzodioxol-5-yl) prop-2-enoyl]benzenesulfonamide and hydroxylamine hydrochloride were added to $50 \mathrm{~mL}$ ethanol and refluxed for $24 \mathrm{~h}$. The resulting compound was obtained in the form of precipitate, filtered, dried under vacuum and recrystallized from methanol.

\subsubsection{4-[3-(1,3-benzodioxol-5-yl)-1,2-oxazol-5-yl] benzenesulfonamide}

Yield: $88 \%$; m. p. $110-112^{\circ} \mathrm{C}$ : Light Yellow crystals; Anal. calc. for $\mathrm{C}_{16} \mathrm{H}_{12} \mathrm{~N}_{2} \mathrm{O}_{5} \mathrm{~S}$ : C 55.81, H 3.51, N 8.14; Found: C 55.83, H 3.52, N 8.17; FT-IR $\left(\mathrm{cm}^{-1}\right): 1621(\mathrm{C}=\mathrm{N}), 2977(\mathrm{CH}-$ Ar), $3347\left(\mathrm{SO}_{2}-\mathrm{NH}_{2}\right) ;{ }^{1} \mathrm{H}$ NMR (DMSO-d6) (ppm): 5.908 (s, $\left.2 \mathrm{H}, \mathrm{O}-\mathrm{CH}_{2}-\mathrm{O}\right), 6.905(\mathrm{~s}, 1 \mathrm{H}, \mathrm{CH}-\mathrm{Ar}), 7.139-7.181(\mathrm{~d}, 1 \mathrm{H}$, $\mathrm{CH}-\mathrm{Ar})$, 7.283-7.320 (d, 1H, CH-Ar), 7.363-7.492 (m, 4H, $\mathrm{CH}-\mathrm{Ar}), 8.310\left(\mathrm{~s}, 2 \mathrm{H}, \mathrm{SO}_{2} \mathrm{NH}_{2}\right)$; ESI-MS (m/z): [M+ +1$]: 345.05$ (Mass: 344.35).

\subsubsection{Procedure for the synthesis of 4-[5-(1,3-benzodioxol-5-yl)-4H-pyrazol-3-yl] benzenesulfonamide [3]}

Hydrazine hydrate and 4-[(2E)-3-(1,3-benzodioxol-5-yl) prop-2-enoyl]benzenesulfonamide were mixed in $50 \mathrm{~mL}$ of ethanol in a round bottom flask and kept on refluxing and following the addition of sulfuric acid ( $1 \mathrm{~mL})$. On completion of the reaction the reaction mixture was poured to the cold water to yield the final product.

\subsubsection{4-[5-(1,3-benzodioxol-5-yl)-4H-pyrazol-3-yl] benzenesulfonamide [3]}

Yield: $80 \%$; m. p. $119-121^{\circ} \mathrm{C}$ : Dark Yellow crystals; Anal. calc. for $\mathrm{C}_{16} \mathrm{H}_{13} \mathrm{~N}_{3} \mathrm{O}_{4} \mathrm{~S}$ : C 55.97, H 3.82, N 12.24; Found: C 55.99, H 3.84, N 12.26; FT-IR $\left(\mathrm{cm}^{-1}\right): 1619(\mathrm{C}=\mathrm{N}), 2971(\mathrm{CH}-$ Ar), $3358\left(\mathrm{SO}_{2}-\mathrm{NH}_{2}\right) ; 3.19-3.26(\mathrm{dd}, 1 \mathrm{H}$, pyrazoline ring, $\left.\mathrm{H}_{\mathrm{B}}\right), 4.07-4.15\left(\mathrm{dd}, 1 \mathrm{H}\right.$, pyrazoline ring, $\left.\mathrm{H}_{\mathrm{A}}\right), 6.10-6.17$ (dd, $1 \mathrm{H}$, pyrazoline ring, $\mathrm{H}_{\mathrm{x}}$ ), ${ }^{1} \mathrm{H}$ NMR (DMSO-d6) (ppm): 6.007 (s, 2H, O- $\left.\mathrm{CH}_{2}-\mathrm{O}\right), 6.881$ (s, 1H, CH-Ar), 7.039-7.095 (d, 1H, $\mathrm{CH}-\mathrm{Ar}), 7.252-7.395(\mathrm{~m}, 4 \mathrm{H}, \mathrm{CH}-\mathrm{Ar}), 8.402\left(\mathrm{~s}, 2 \mathrm{H}, \mathrm{SO}_{2} \mathrm{NH}_{2}\right)$, 11.113 (s, 1H, NH); ESI-MS (m/z): $\left[\mathrm{M}^{+}+1\right]$ : 344.07 (Mass: 343.36).

\subsection{Antimicrobial screening}

Antimicrobial screening of the compounds (1-3) was performed by disc diffusion on the gram positive and gram-negative pathogens [S. aureus (ATCC-25923), S. epidermidis (ATCC-29887), E. coli (ATCC-25922), P. mirabilis (ATCC-25933) following the same protocol as discussed in the literature [43-53].

\subsection{Molecular docking assessment}

Molecular docking assessment was performed by Aautodock-tools 1.5.6, Autodock-Vina, and Pymol to estimate the binding affinity and the $\mathrm{H}$-bonding in between the synthesized compounds (1-3), ciprofloxacin with the amino acid residues of the protein GlcN-6-P-synthase, (PDB: 2VF5) [54-56].

\subsection{Percent viability of the cells assessment}

The percent viability of the cells for the prepared compounds 1-3 was performed against HepG2 (Human hepatocellular carcinoma). The cells were grown Dulbecco's modified Eagle's medium with $10 \%$ heat-activated fetal bovine serum, and $(100$ units $/ \mathrm{mL}$ penicillin, $100 \mathrm{mg} / \mathrm{mL}$ streptomycin and $2.5 \mathrm{mg} / \mathrm{mL}$ amphotericin B) and incubated at $37^{\circ} \mathrm{C}$ in an atmosphere containing (95\% air/5\% $\left.\mathrm{CO}_{2}\right),[57,58]$.

\section{Conclusion}

A series of three compounds with different heterocyclic nucleus was designed and calculated for bioactivity and physicochemical properties. The compounds were found to possess the bioactivity score in the zone for bioactive compounds. The compounds were synthesized, characterized and evaluated for antimicrobial effects and the findings revealed that the compound-3 portrayed better antimicrobial potential than ciprofloxacin. Molecular docking assessment was also established for a better understanding of the antimicrobial potential in terms of binding affinity and $\mathrm{H}$-bonding with the residues of GlcN-6-Psynthase. The Results of the docking assessment strongly recommended the experimental finding and represented that compound-3 has better $\mathrm{H}$-bonding with the protein residues than the standard.

Acknowledgements Dr. Mohammad Arshad, is highly thankful to the Dean, College of Medicine, AI-Dawadmi, Shaqra University, KSA for his cooperation to accomplish this work.

\section{Compliance with ethical standards}

Conflict of interest The authors declare that they have no conflict of interest. 


\section{References}

1. Gastmeier P, Sohr D, Geffers C et al (2005) Mortality risk factors with nosocomial Staphylococcus aureus infections in intensive care units: results from the German Nosocomial Infection Surveillance System (KISS). Infection 33:50-55

2. Neu HC (1992) The crisis in antibiotic resistance. Science 257:1064-1073

3. Arshad M, Khan MS (2018) Synthesis, characterization, computational, antimicrobial screening, and MTT assay of thiazolidinone derivatives containing the indole and pyridine moieties. Russ J Gen Chem 88(10):2154-2162

4. Arshad M (2014) An insight to the synthetically obtained triazole possessing numerous biological activities. Int J Pharm Pharm Sci 9(4):16-24

5. Arshad M, Khan TA (2014) 1-(Substituted-phenylsulfonyl)$2 \mathrm{H}$-thieno [2, 3-d][1, 3] oxazine-2, 4 (1H)-dione: drug likeness, physicochemical, synthesis, characterization, antibacterial and cytotoxicity assessment. Int J Pharm Sci Res 5:149-162

6. Arshad M (2014) 4-[(1E)-3-(Substituted-phenyl)-3-oxoprop1-en-1-yl] benzenesulfonamide: design, computational, synthesis, characterization and antibacterial assessment. Int J Pharm Sci Res 5(4):149-162

7. Arshad M (2014) 1, 3, 4-Oxadiazole nucleus with versatile pharmacological applications: a Review. Int J Pharm Sci Res 5(4):1000-1013

8. Alodeani EA, Arshad M, Izhari MA (2015) Antileishmanial activity and computational studies of some hydrazone derivatives possessing quinoline nucleus. Eur J Pharma Med Res 2(7):324-328

9. Arshad M, Bhat AR, Pokharel S, Lee EJ, Athar F, Choi I (2014) Synthesis, characterization and anticancer screening of some novel piperonyl-tetrazole derivatives. Eur J Med Chem 71:229-236

10. Prasanthi G, Prasad KV, Bharathi K (2013) Design, synthesis and evaluation of dialkyl 4-(benzo[d][1,3]dioxol-6-yl)-1,4-dihydro-2,6-dimethyl-1-substituted pyridine-3,5-dicarboxylates as potential anticonvulsants and their molecular properties prediction. Eur J Med Chem 66:516-525

11. Aboul-Enein MN, El-Azzouny AA, Attia MI, Maklad YA, Amin KM, Abdel-Rehim M, El-Behairy MF (2012) Design and synthesis of novel stiripentol analogues as potential anticonvulsants. Eur J Med Chem 47:360-369

12. Alizadeh BH, Foroumadi A, Emami S, Khoobi M, Panah F, Ardestani SK, Shafiee A (2010) Isochaihulactone analogues: synthesis and anti-proliferative activity of novel dibenzylbutyrolactones. Eur J Med Chem 45:5979-5984

13. Yeo H, Li Y, Fu L, Zhu JL, Gullen EA, Dutschman GE, Lee Y, Chung R, Huang ES, Austin DJ, Cheng YC (2005) Synthesis and antiviral activity of helioxanthin analogues. J Med Chem 48:534-546

14. Feng W, Satyanarayana M, Tsai YC, Liu AA, Liu LF, LaVoie EJ (2009) Novel topoisomerase I-targeting antitumor agents synthesized from the $\mathrm{N}, \mathrm{N}, \mathrm{N}$-trimethylammonium derivative of ARC-111, 5H-2, 3-dimethoxy-8, 9-methylenedioxy-5-[(2-N, N, $\mathrm{N}$-trimethylammonium) ethyl] dibenzo $[\mathrm{c}, \mathrm{h}][1,6]$ naphthyridin-6-one iodide. Eur J Med Chem 44:3433-3438

15. Beghyn TB, Charton J, Leroux F, Henninot A, Reboule I, Cos P, Maes L, Deprez B (2012) Drug-to-genome-to-drug, step 2: reversing selectivity in a series of antiplasmodial compounds. J Med Chem 55:1274-1286

16. Khanapure SP, Garvey DS, Young DV, Ezawa M, Earl RA, Gaston RD, Fang $X$, Murty M, Martino A, Shumway M, Trocha M, Marek P, Tam SW, Janero DR, Letts LG (2003) Synthesis and structure-activity relationship of novel, highly potent metharyl and methcycloalkyl cyclooxygenase-2 (COX-2) selective inhibitors. J Med Chem 46:5484-5504
17. Bhat AR, Arshad M, Lee EJ, Pokharel S, Choi I, Athar F (2013) Synthesis, characterization, and anti-amoebic activity of $\mathrm{N}$-(Pyrimidin-2-yl)benzenesulfonamide derivatives. Chem Biodivers 10:2267-2277

18. Alodeani EA, Izhari MA, Arshad M (2014) 4-[(1E)-3-(Substitutedphenyl)-3-oxoprop-1-en-1-yl] benzenesulfonamide: design, computational, synthesis, characterization and antibacterial assessment. Eur J Biomed Pharm Sci 1(3):504-527

19. Parker WB (2009) Enzymology of purine and pyrimidine antimetabolites used in the treatment of cancer. Chem Rev 109:2880

20. Alodeani EA, Arshad M, Izhari MA (2015) Burn skin pathogens: isolation, identification and antimicrobial activity pattern against pyrazole derivatives. Am J Pharm Tech Res 5(6):150-158

21. Karrouchi K, Ramli SRY, Taoufik J, Mabkhot YN, Al-aizari FA, Ansar $M$ (2018) Synthesis and pharmacological activities of pyrazole derivatives: a review. Molecules 23:134

22. Zhang H-Z, Zhao Z-L, Zhou C-H (2018) Recent advance in oxazole-based medicinal chemistry. Eur J Med Chem 144:444-492

23. Abhale YK, Sasane AV, Chavan AP, Shekh SH, Deshmukh KK, Bhansali $S$ et al (2017) Synthesis and antimycobacterial screening of new thiazolyl-oxazole derivatives. Eur J Med Chem 132:333-340

24. Moraski GC, Chang M, Villegas-Estrada A, Franzblau SG, Möllmann U, Miller M, Tseng C-H, Lin C-K, Chen Y-L, Tseng C-K, Lee J-Y, Lee J-C (2018) Discovery of naphtho [1, 2-d] oxazole derivatives as potential anti-HCV agents through inducing heme oxygenase-1 expression. Eur J Med Chem 143:970-982

25. Seenaiah D, Ramachandra Reddy P, Mallikarjuna Reddy G, Padmaja A, Padmavathi V, Siva krishna N (2014) Synthesis, antimicrobial and cytotoxic activities of pyrimidinyl benzoxazole, benzothiazole and benzimidazole. Eur J Med Chem 77(22):1-7

26. Zhou J, Jin J, Zhang Y, Yin Y, Chen X, Xu B (2013) Synthesis and antiproliferative evaluation of novel benzoimidazole-contained oxazole-bridged analogs of combretastatin A-4. Eur J Med Chem 68:222-232

27. Biersack B, Effenberger K, Knauer S, Ocker M, Schobert R (2010) $\mathrm{Ru}$ (n6-arene) complexes of combretastatin-analogous oxazoles with enhanced anti-tumoral impact. Eur J Med Chem 45:4890-4896

28. Kumar A, Ahmad P, Maurya RA, Singh AB, Srivastava AK (2009) Novel 2-aryl-naphtho [1, 2-d] oxazole derivatives as potential PTP-1B inhibitors showing antihyperglycemic activities. Eur J Med Chem 44:109-116

29. Mariappan G, Saha BP, Datta S, Kumar D, Haldar PK (2011) Design, synthesis and antidiabetic evaluation of oxazolone derivatives. J Chem Sci 123:335-341

30. Semenyuta I, Kovalishyn V, Tanchuk V, Pilyo S, Zyabrev V, Blagodatnyy $V$ et al (2016) 1, 3-Oxazole derivatives as potential anticancer agents: computer modeling and experimental study. Comput Biol Chem 65:8-15

31. Sowmya DV, Basha SS, Uma P, Devi M, Lavanyalatha Y, Padmaja A, Padmavathi V (2017) Synthesis, antimicrobial, and anti-inflammatory activities of acetamido pyrrolyl azoles. Med Chem Res 26:1010-1021

32. El Shehry MF, Ghorab MM, Abbas SY, Fayed EA, Shedid SA, Ammar YA (2018) Quinoline derivatives bearing pyrazole moiety: synthesis and biological evaluation as possible antibacterial and antifungal agents. Eur J Med Chem 143:1463-1473

33. Padmaja A, Payani T, Dinneswara Reddy G, Padmavathi V (2009) Synthesis, antimicrobial and antioxidant activities of substituted pyrazoles, isoxazoles, pyrimidine and thioxopyrimidine derivatives. Eur J Med Chem 44:4557-4566

34. Chougala BM, Samundeeswari S, Holiyachi M, Shastri LA, Dodamani S, Jalalpure S, Dixit SR, Joshi SD, Sunagar VA (2017) Synthesis, characterization and molecular docking studies of substituted 4-coumarinylpyrano[2,3-c]pyrazole derivatives as 
potent antibacterial and anti-inflammatory agents. Eur J Med Chem 125:101-116

35. Shaabana OG, Issac DAE, El-Tombary AA, Abd El Wahab SM, Abdel Wahab AE, Abdelwaha IA (2019) Synthesis and molecular docking study of some 3,4-dihydrothieno[2,3-d] pyrimidine derivatives as potential antimicrobial agents. Bioorgan Chem 88:102934

36. Alodeani EA, Arshad M, Izhari MA (2015) Anti-uropathogenic activity, drug likeness, physicochemical and molecular docking assessment of (E-)-N'-(substituted-benzylidene)-2-(quinolin-8yloxy) acetohydrazide. Asian Pac J Trop Biomed 5(8):676-683

37. Alodeani EA, Arshad M, Izhari MA (2015) Antileishmanial activity and computational studies of some hydrazone derivatives possessing quinoline nucleus. Asian Pac J. Health Sci 2(2):41-47

38. Alodeani EA, Arshad M, Izhari MA (2015) Drug likeness and physicochemical properties evaluation of the alkaloids found in black pepper: piperine, piperidine, piperettine and piperanine. Eur J Pharma Med Res 2(6):296-301

39. Arshad M, Shadab M (2017) Antimicrobial screening of crude extract of Zingber officinalle: chemical components, drug likeness, physicochemical property and molecular docking assessment. Eur J Pharm Med Res 4(3):364-368

40. Arshad M, Shadab M (2017) Antimicrobial screening of crude extract of pluchea arabica: chemical components, drug likeness, physicochemical property and molecular docking assessment. Eur J Pharm Med Res 4(4):447-454

41. Arshad M (2017) Synthesis, characterization, antimicrobial and computational studies of some sulfonamide derivatives possessing thiadiazole and indole nucleus. Eur J Pharm Med Res 4(12):511-517

42. Arshad M (2018) 1-(Substituted-phenylsulfonyl)-2Hthieno[2,3d] [1,3]oxazine-2,4(1H)-dione: drug likeness, physicochemical, synthesis, characterization, antibacterial and cytotoxicity assessment. Int J Pharm Sci Res 9:12-19

43. Arshad M (2018) 4-[(1E)-3-(Substituted-phenyl)-3-oxoprop1-en-1-yl]benzenesulfonamide: design, computational, synthesis, characterization and antibacterial assessment. Int J Pharm Sci Res 9:35-41

44. Arshad M, Bhat AR, Hoi KK, Choi I, Athar F (2017) Synthesis, characterization and antibacterial screening of some novel 1, 2, 4-triazine derivatives. Chin Chem Lett 28(7):1559-1565

45. Iram N, Khan MS, Jolly R, Arshad M, Alam M, Alam P, Khan RH, Firdaus $F$ (2015) Interaction mode of polycarbazole-titanium dioxide nanocomposite with DNA: molecular docking simulation and in vitro antimicrobial study. J Photochem Photobiol B Biol 153:20-32

46. Kareema A, Arshad M, Nishat N (2016) Herbo-mineral based Schiff base ligand and its metal complexes: synthesis, characterization, catalytic potential and biological applications. J Photochem Photobiol B Biol 160:163-171

47. Nami SAA, Arshad M, Shakir M, Khan MS, Alam M, Lee D-U, Park S, Sarikavakli N (2015) Morphological, structural, molecular docking and biocidal studies of newly synthesized Ppy-MA/ TiO2 nanocomposites. Polym Adv Technol 26(12):1627-1638

48. Bushra R, Shahadat M, Khan MA, Adnan R, Arshad M, Rafatullah M, Naushad M (2015) Preparation of polyaniline based nanocomposite material and their environmental applications. Int J Environ Sci Technol 12(11):3635-3642

49. Nami SAA, Khan MS, Arshad M, Raza MA, Khan I (2017) Spectral, morphological, and antibacterial studies of conducting copolymers, Ppy-MA, and their nanocomposites, Ag@ Ppy-MA. Polym Adv Technol 28:10-19

50. Arshad M, Tazeem, Bhat AR, Athar F (2011) Heterocyclic azoles and their biological application as antimicrobials. J Nat Sci Biol Med 2(3):131-132

51. Nayab PS, Arif R, Arshad M, Uddin R (2015) Synthesis, characterization, antibacterial, DNA binding and molecular docking studies of novel N-substituted phthalimides. Heterocycl Lett 5(2):223-239

52. Tazeem, Arshad M, Bhat AR, Athar F (2011) Synthesis, characterization of heterocyclic compounds and their application as antibacterial therapeutic agents. J Nat Sci Biol Med 2(2):1-156

53. Tuhfa, Younus Wani M, Arshad M, Tazeem, Athar F (2011) Chalcone scaffold: Synthesis, modification, characterization, molecular properties and screening against microbes. J Nat Sci Biol Med 2(3):116

54. Morris GM, Goodsell DS, Halliday RS, Huey R, Hart WE, Belew RK et al (1998) Automated docking using a Lamarckian genetic algorithm and an empirical binding free energy function. J Comput Chem 19:1639-1662

55. Mouilleron S, Badet-Denisot MA, Golinelli-Pimpaneau B (2008) Ordering of $C$-terminal loop and glutaminase domains of glucosamine-6-phosphate synthase promotes sugar ring opening and formation of the ammonia channel. J Mol Biol 377(4):1174-1785

56. Trott O, Olson AJ (2010) AutoDock Vina: improving the speed and accuracy of docking with a new scoring function, efficient optimization and multithreading. J Comput Chem 31:455-461

57. Gupta MK, Neelakantan TV, Sanghamitra M, Tyagi RK, Dinda A, Maulik S, Mukhopadhyay CK, Goswami SK (2006) An assessment of the role of reactive oxygen species and redox signaling in norepinephrine-induced apoptosis and hypertrophy of $\mathrm{H} 9 \mathrm{c} 2$ cardiac myoblasts. Antioxid Redox Signal 8:1081-1093

58. Mosmann T (1983) Rapid colorimetric assay for cellular growth and survival: application to proliferation and cytotoxicity assays. J Immunol Methods 65:55. https://doi.org/10.1016/00221759(83)90303-4

Publisher's Note Springer Nature remains neutral with regard to jurisdictional claims in published maps and institutional affiliations. 